\title{
Harvesting sulla for yield and quality
}

E.M.K. MINNEÉ, S.J. BLUETT and S.L. WOODWARD Dexcel, P B 3221, Hamilton elena.minnee@dexcel.co.nz

\begin{abstract}
Deciding when to harvest sulla (Hedysarum coronarium) can be a compromise between herbage yield and forage nutritive quality. Sulla, which grows up to $1.5 \mathrm{~m}$ tall, is tolerant of dry conditions and has been shown to have beneficial effects on ruminant production and health. A trial was conducted at Hamilton, New Zealand, to compare crop yield and nutritive quality of sulla harvested when it reached 30, 45, 60 and $75 \mathrm{~cm}$ high (retaining a stubble of $15 \mathrm{~cm}$ ) over one growing season. Results show harvesting at $75 \mathrm{~cm}$ versus $30 \mathrm{~cm}$ increased total dry matter (DM) yield by $30 \%$. Increasing harvest height increased total fibre content from 13.1 to $20.1 \mathrm{~g} / 100 \mathrm{~g} \mathrm{DM},(\mathrm{P}<0.001)$ and lowered crude protein concentration from 18.8 to $15.7 \mathrm{~g} / 100 \mathrm{~g}$ $\mathrm{DM}$, $(\mathrm{P}<0.001)$, soluble sugars from 23.1 to $21.5 \mathrm{~g} /$ $100 \mathrm{~g}$ DM, $(\mathrm{P}<0.01)$ and predicted organic matter digestibility from 89 to $82 \mathrm{~g} / 100 \mathrm{~g} \mathrm{DM},(\mathrm{P}<0.001)$. These factors were associated with the decline in
\end{abstract}

proportion of leaf with increasing harvest height from 49.1 to $31.6 \%$ of harvested DM. Increased harvest height reduced the concentration of calcium and potassium in the $\mathrm{DM}$ by about $10 \%(\mathrm{P}<0.01)$, however there was a larger reduction in sulphur concentration with increased maturity $(\mathrm{P}<0.001)$ from 0.24 to $0.18 \%$ of DM $(\mathrm{P}<0.001)$. Phosphorous and magnesium concentrations were unaffected. Total condensed tannins (CT) declined from 6.0 to $5.5 \%$ DM with increased harvest height $(\mathrm{P}<0.001)$, but all values were within the range regarded as beneficial for animal performance. Concentrations of all nutrients indicated a very good quality forage for sheep and cattle at all harvest heights and harvesting for maximum yield may not compromise quality. These results, although agronomically important, were small and may not produce noticeable effects on animal production.

Keywords: condensed tannins, harvest height, Hedysarum coronarium, legume 
